\title{
Lighting Methods Employed in Harvest of Fishery Products: A Narrative Review
}

\author{
Charles Odilichukwu R. Okpala ${ }^{1,2, *}$, Giacomo Sardo $^{1}$, Sergio Vitale ${ }^{1}$ \\ ${ }^{1}$ Institute for Coastal Marine Environment - National Research Council (IAMC-CNR), Mazara del Vallo, Italy \\ ${ }^{2}$ Educare and Skills Training Network, Middlesex HA88EJ, United Kingdom
}

Copyright $\mathrm{C} 2017$ by authors, all rights reserved. Authors agree that this article remains permanently open access under the terms of the Creative Commons Attribution License 4.0 International License

\begin{abstract}
Fishermen since time immemorial have employed various lighting methods aimed for favourable/successful harvest of fishery products. The latter on the other hand have evolved with habitat constituents for example, the waters, light and other external factors, which contribute to evolve the sensory adaptations. Whilst there is considerable literature about lighting approaches/methods employed in harvest of fishery products, no appraisal concerning the state-of-the-art to best of our knowledge has been performed. In this review, (some) relevant information about lighting methods employed in harvest of fishery products will be summarized under the following sub-headings: (a) Light as resource for fishing; (b) Eye of fish for vision and survival; (c) Catching the fish with light: experimental methods and instrumentation; (d) Light intensities that looks at: (i) attraction and reaction of fish; (ii) active escape of fish; (iii) induced stress of fish; as well as (e) Simulated trawls and conducted surveys. Some recommendations to direct future studies are also summarized.
\end{abstract}

Keywords Fish Movement, Light Intensity, Eye of Fish, Vision, Simulation, Survey

\section{Introduction}

As the global demand for seafood products continue to increase, more regulations that aim to protect fishing ground(s) continue to emerge [1-3]. Since time immemorial, fishermen have sought to achieve successful harvest using varying light types. Likewise, the fish have evolved with such constituents of habitat as the waters, light and other external factors, which have contributed to evolve the sensory adaptations. Traditionally and many years ago along Atlantic coast of North America, torch lights - a method probably adopted by (Red) Indians, which involved combustible material placed on a stick mounted on bow of typical boat of that time. The flame either burned and or combusted with either kerosene and or gasoline [4]. In fact, Earll [5] well described the process in this quote below:

"The fishermen usually go to the shore late in the afternoon and time their departure so as to reach the fishing grounds shortly after sunset. As soon as it comes sufficiently dark, the fire is lighted, one man takes his position in the stern to steer the boat and another stations himself in the bow, armed with a dip-net for securing the fish as they gather in little bunches just in front of the light. The remaining members of the crew row the boat rapidly through the water, while the men in the bow are busily engaged in throwing the fish into the boat by means of his dip-net. Great numbers of herring are attracted by light and it is not uncommon for fifteen or twenty barrels to be taken in a few hours".

Considerably, a number of earlier authors [4,6-7] well agree that the routine impressionable use of lights to attract fish may only be sometimes successful underpinned by how fish responds to different light types. Largely and over decades, the characteristic features of fishing - lighting endeavours past have focused on fish responses to light believed to depend on factors such as environment, physiological state, age of fish, type of stimuli, intensity of light, water temperature and illumination [4, 6-7]. Advances in light intensities for fishing activities in current millennium have impacted on fishery resources, which relate with relevant existent fishing disputes. Nevertheless, the increased use of different fishing light intensities in view to boost the fishery harvest that seek sustainable practices (fishing light intensity and luring time) and balance with (anticipated) profit remains among crucial concerns for responsible sectors of academia, government, as well as industry [8].

Recent years, the conducted light(ing) - fishery harvest studies have focused on issues such as phototaxis behaviour of fish under light [9-11], optimal intensity of fishing lights [12-13], visual physiology [14], physical nature of fishing lights (illumination under water) and optimal intensity of fishing light to affect visual-physiological reaction of fish [15]. Moreover, the manner by which fish species are able to discriminate between the approaching trawl and other 
supplementary fish-friendly components and under different/varying light intensities/levels has not been well understood. Could it perhaps depend on the visual capacity of (targeted) fish species as well as either colour and or the reflectance of gear? Could it also perhaps associate with the ambient light field, reflectance of sediments and fish orientation relative to the trawl [16]? Principally, responsible fishing necessitates the compliance to various fishing regulations, the avoidance either to disturb non-target fish species and or of by-catch, the non-discard of used light sticks and or batteries into the sea, as well as the avoidance of either the use of lights near the sea turtle nesting beaches and or of fishing on spawning aggregations [17]. Besides, the capture/ mortality of non-targeted fish species remains among pressing issue(s) concerning management of worldwide fisheries [18]. With respect to light intensities and its most appropriate level of use in view to achieve improved yet economical/sustainable fishery harvest, no global consensus seems to be reached anytime soon. Although a considerable number of studies have evidenced light employed for fishery harvest and its related concerns, no review to best of our knowledge about the state-of-the-art has been carried out. In order to address the state-of-the-art and fill this gap, some relevant literatures of lighting used for harvest of fisheries products are summarized. This paper has been constructed with the following sub-headings: (a) Light as resource for fishing; (b) Eye of fish for vision and survival; (c) Catching the fish with light: experimental methods and instrumentation; (d) Light intensities I: fish attraction and reaction; (e) Light intensities II: Active escape of fish; (f) Light intensities III: Induced stress of fish; and (g) Simulated trawls and conducted surveys. At the end, some recommendations are given to help guide the future studies.

\section{Review of Relevant Literatures}

\section{Light as Resource for Fishing}

Intensity and wavelength are key elements that characterize light. It is well known that light propagates through Eq. (1):

$$
\mathrm{I}=\mathrm{I}_{0}{ }^{\mathrm{e}}{ }^{(-\mathrm{kz})}
$$

where I = Intensity at depth $\mathrm{z} ; \mathrm{I}_{0}=$ Surface intensity; and $\mathrm{k}=$ an extinction coefficient. The intensity of point source light at distance $r$ from the source can then be approximated by the Eq. (2):

$$
\mathrm{I}=\mu \mathrm{N}_{0}\left(\mathrm{r}_{0} / \mathrm{r}\right)^{2 \mathrm{e}-\mathrm{a}(\mathrm{r}-\mathrm{r} 0)}
$$

where $\mathrm{a}=$ volume absorption coefficient; $\mathrm{N}_{0}=$ surface radiance-per-unit-area, and $\mathrm{r}_{0}=$ the radius of the source. In general, light measurement and its intensity integrate a range of wavelengths over unit length of time as well as area of illumination. Given the differences in measures and wavelengths, energy content of light is deemed wavelength dependent. To characterize fish response to light has come with much challenge given the differences in sensitivities to different wavelengths [19]. Herein, the different light measurements and typical light levels can be linked by comparing Tables 1 and 2, which has allowed for further computations about various light intensities and identification of, on one hand, the natural light of different (environmental-based) conditions such as sky at noon, direct sunlight, dusk-dawn, starlight (which are natural lights), and on the other hand, the artificially/man-made light such as the fluorescent and mercury lamps (artificial) [19]. These measurements could indeed serve as reference candidates when ascertaining light intensity equivalents, which can help in comparing with other light (intensity) units. Contextualizing Tables 1 and 2, the relatedness as well as relevance of such different light intensity units and how they are employed in related/relevant studies can therefore be further appreciated.

Table 1. Different light measurement conversions

\begin{tabular}{|c|c|}
\hline Light Values & Alternative Equivalence \\
\hline 10.76 lux & 1 footcandle \\
\hline 1000 lux & 1 lambert \\
\hline 1 lux & 1 lumens $/ \mathrm{m}^{2}$ \\
\hline 98 lux & $\sim 1 \mathrm{watt} / \mathrm{m}^{2}$ \\
\hline 41 lux & $\sim 1 \mathrm{mE} / \mathrm{m}^{2} / \mathrm{s}$ \\
\hline $1 \mu$ Einstein & $6.02 \times 10^{17} \mathrm{photons}$ \\
\hline $1 \mathrm{mwatt} / \mathrm{cm}^{2}$ & $1 \mathrm{watt} / \mathrm{m}^{2}$ \\
\hline
\end{tabular}

Sourced from: Feist and Anderson (1991)

Table 2. Intensities of different light sources

\begin{tabular}{|c|c|c|c|}
\hline Condition & Lux & Watt $/ \mathbf{m}^{2}$ & $\mathbf{m E} / \mathbf{m}^{2} / \mathbf{s}$ \\
\hline Sky at noon & 81,667 & 834 & $\sim 2000$ \\
\hline Direct sunlight & $5.19 \times 10^{8}$ & $5.3 \times 10^{6}$ & $\sim 1.3 \times 10^{7}$ \\
\hline Dusk-dawn & 5 & 0.05 & $\sim 0.1$ \\
\hline Starlight & 0.03 & 0.0003 & $\sim 0.0007$ \\
\hline Fluorescent (40 watt) & 2100 & 21 & $\sim 51$ \\
\hline Mercury lamp (100 watt) & $9.4 \times 10^{7}$ & $9.6 \times 10^{5}$ & $\sim 2.3 \times 10^{6}$ \\
\hline
\end{tabular}

Sourced from: Feist and Anderson [19]

Major light types applicable to fish harvest are showed in Fig. 1. The sun has always led as the greatest source of light. In addition, fishermen have long performed their fishing activity in the morning just before and after sunrise and at dusk, just before sunset for two major reasons, namely: a) the fish are fed at these times; and b) light is also limited (for the fish) at these times. Moreover, the moon would offer far much-reduced amount of light even though it is believed that some fish species such as the broadbill swordfish could be caught at about the full moon whereas the yellowfin tuna could be caught at about the new moon situation(s) and up till now, this phenomenon appears yet not confirmed [17]. Bioluminescence, that is, when some chemical reaction with certain marine organisms produces light, can be emitted among fish species so as either to see at night, communicate, attract mate/prey, and or repel predators. On the other hand, 
light can equally be sourced and artificially by the use of torches, etc. This approach has had a long history with fishermen around the globe. The use of chemical light sticks also existed. It played some useful function, for example, in the attraction of swordfish as well as its use in the pelagic long-lines. In addition, the large commercial fishing boats employed (artificial) light methods to attract (small) pelagic fish species toward the harvest by either the use of nets and or any other mechanized means. Further, the use of underwater lights either submerged below the boat and or over the net has served as great resource to lure some targeted fish species [17].

\section{Eye of Fish for Vision and Survival}

The eyes of aquatic species have been known to demonstrate numerous adaptations to both underwater and aerial vision [20]. Describing the eye of typical (edible) fish for example, apart from it being the visual apparatus with components and functions, the structure basically constitutes of eyeball, tunics and retina. The transparent refractive systems allows for light passage into the retina to form visual images. The presence of accessory organs such as the eyelid, conjunctiva, lacrimal apparatus and extra-ocular muscles contributes to facilitate the eyes' functionality [21]. Furthermore, how retina functions allow the eye to adapt varying light intensities, which underpins visual photo-transduction, the latter, a process by which light converts into electrical signals within the rods and cones, as well as photosensitive ganglion cells [19]. Generally, the working action of refraction and reflection, the thickness of sclerotic and cornea, the shape of lens, the conformation of either iris and or pupil, as well as the vascularization of eyeball has contributed to the eye of fish adapting to wide range of environment(s) [21]. Besides, a number of fish species have paired image-forming eyes and relative to the retina, the lens movement probably enhances its accommodation. In fact, the retino-motor response (movement of the outer retina-receptor segments relative to pigment layer) within the eye probably supports fish's ability to adequately focus and respond to the diverse light intensities [19]. Moreover, the eye of some fish species, for example Oncorhynchus spp. are able to see at both bright and dim light situations, which has been attributed to the large number of rods and cones. In addition, some pelagic fish species can see distances beyond 50 feet $(15.2 \mathrm{~m})$ even under optimal conditions [19, 22-23].

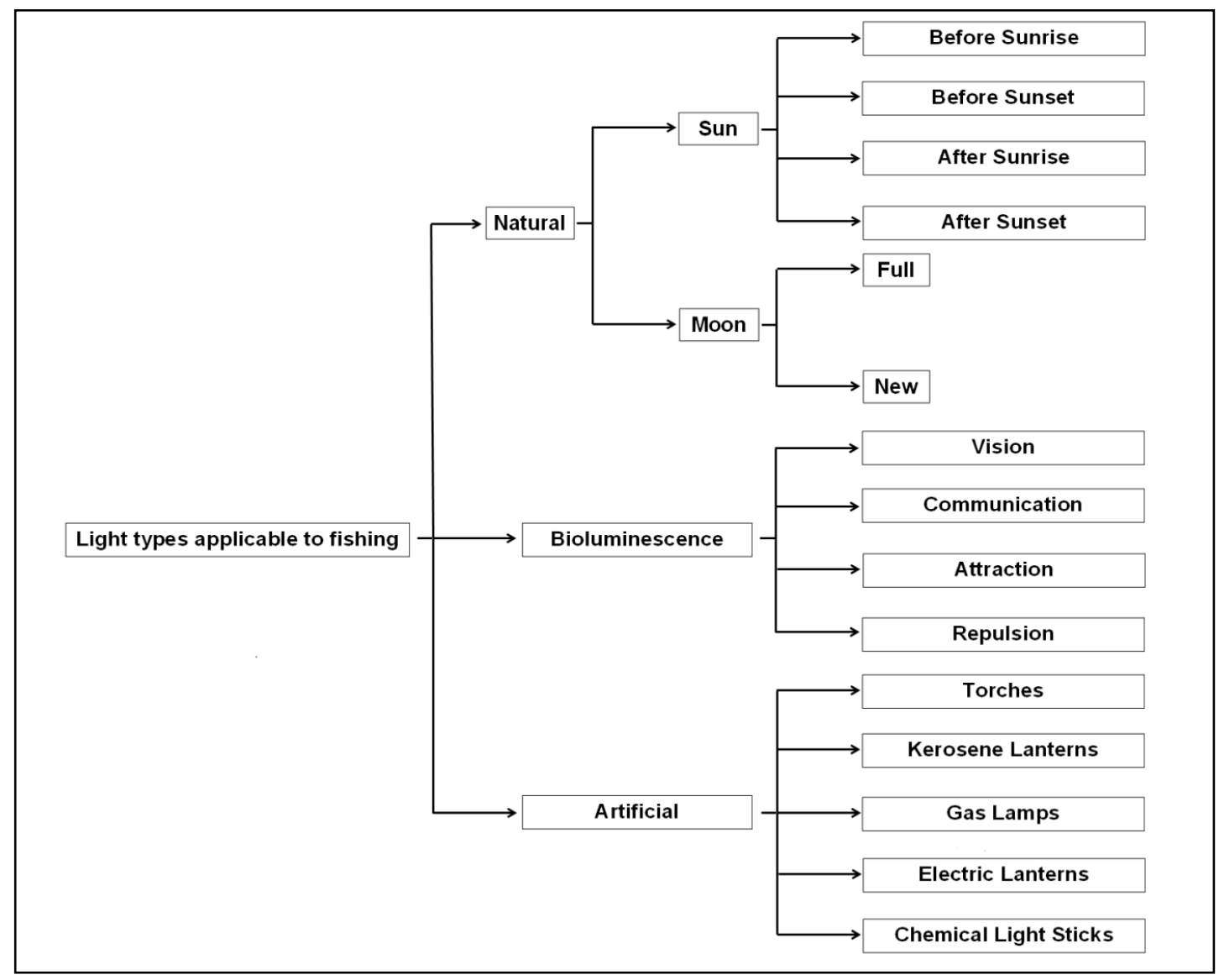

Figure 1. Classification of major light types applicable to fishing 
Whilst light helps fish's orientation to perform diurnal activities, the light variations can influence both fish behavior and activity rhythm. Many fish species of commercial interest have shown to be affected by artificial light as well as by schooling / swimming towards a given light source. Fishermen have thus employed diverse lighting systems to exploit this behavior and improve the catch [24-27]. The optical environment where fish both dwell and forage can dramatically vary with respect to time (hour, day, month as well as season). In that the low illumination can affect both visual ability and capability of fishes, the need to understand this context has led to studies concerning illumination thresholds purposed to feasibly predict how existent aquatic species respond to various forage conditions [28-29]. In addition, understanding the light-dependency of visual-foraging fish species is relevant not only for growth and survival but useful for fish energetics [28]. By visual and mechano-sensory systems, schooling also reveals how light pattern is maintained among fish species. At the low light intensities, schooling can be affected probably given visual limitations. Among aquatic species, dissipation of schools can vary by light intensities [30]. Earlier investigators like Dragesund [31] as well as Stickney [4] showed how fish schools differently to light, such as (a) fish descend and pack together; (b) fish disperse; (c) fish rise toward light, then shortly descend; and or (d) fish pack together, then rise toward the light. Photo-movement, that is, how fish (or any other organism) respond to light, can be in four different ways, namely: aggregation (formation of lusters), phototaxis (movement either towards or away light source), photokinesis (freezing or continuous motion until light is no longer sensed) as well as vertical diurnal migration (daily up/down in water column). Further, photokinesis and phototaxis can be either positive or negative [17]. Besides, the optical properties of water column are affected by light intensity as well as the relative absorption of the water itself [32-33].

The vision of eye of fish is primarily important for its survival, which efficiently connects by photoreception [32, 34]. The degree of response of fish to light can vary at developmental stage(s). Also, light sensitivity can increase by behavior of smolting and water depths hence, light directly may associate with fish behavior [19]. Given the electro-mechanical advances of light technology recent years have seen palpable progress concerning light intensity of fishing lamps [8]. Possibly, the lack of adequate light may reduce how smaller fish are able to detect as well as respond to a moving net $[29,35]$. Besides, some fish species have bigger eyes compared to the others, whereas some can see even in the extreme of dim light situations. Night active fish (nocturnal) species tend to have larger eyes compared to the day active ones (diurnal) [17]. Besides, given that light would either attract or repel fish whether it is either continuous or pulsing largely based on light intensity, light responses tend to vary either between species, at any given stock(s) and or water velocity [19]. Given the trawl's visibility to fish and notwithstanding that the direction of the net primarily accounts for the differences in trawl catchability between day and night [36], the vision of fish species by sensory stimuli may associate directly with herding behavior. Flatfish, for example, obtains a directional nature of sensorial stimuli/information. Fish herding as well as gear avoidance therefore remains an important function that supplements fish vision [16]. Common visual adaptation in fish species have long involved either with similar habitat or environment as some experimented evidence has revealed there existing some correlation between either the behaviors, visual system and or activity rhythms [34, 37]. By sensory capabilities of fish to respond to trawls, vision with light account for among limiting factors in net detection [18]. Not only that the direct test of visual detection of catch rates still remains challenging, the selectivity of trawls can provide some clues [38]. While the stimulation of visual and other senses can push the fish away [39], some species differ by behavior and dependent on $24 \mathrm{~h}$ cycle as well as visual characteristics [34, 40]. Interspecific trophic relations also contribute to the behavior as well as visual system of fish species [34, 41]. Color can add additional complexity to the overall vision probably to improve how the fish would perceive the environment. Because color vision can increase with chromatic perception, either the resolution and or acuity may diminish given the extra space that would be required for the multiple classes of retino-photoreceptor cells [33]. Not only that fish vision as the principal sensory unit actively controls its behavior and corresponding orientation to the trawl gear, there has been growing interest as about how it responds to available (ambient) light up to the (simulated/field) trawl gear [38]. For example, adult fish might exhibit some greater sensitivity to light response to trawl, which can occur at light intensities of between $10^{-5}$ up to $10^{-6} \mu \mathrm{mol}$ photons $\mathrm{m}^{-2} \mathrm{~s}^{-1}$. However, the variation in visual sensitivity among species could be linked to such factors as the differences in fish species and life stage, environmental conditions as well as experimental methods [18]. 
Table 3. Evidence of experimental aspects of published light-related fish studies

\begin{tabular}{|c|c|c|c|c|}
\hline References & Target & Lighting features & Experimental Set-up & Other remarks \\
\hline Blexter [7] & $\begin{array}{l}\text { Spectral sensitivity of herring } \\
\text { behavior to light intensities }\end{array}$ & $\begin{array}{l}\text { Light bulb powered at } 6 \mathrm{~W} \text { or } 36 \mathrm{~W} \text { kept at } \\
\qquad 12 \text { volts }\end{array}$ & $\begin{array}{l}20 \text { juvenile herring kept in glass tanks } \\
\text { illuminated on one side }\end{array}$ & $\begin{array}{c}\text { Behavior studied by phototaxis and feeding; } \\
\text { Spectral sensitivity curves for different behaviors } \\
\text { determined. }\end{array}$ \\
\hline Stickney [4] & $\begin{array}{l}\text { Bio-related explanations conducive to } \\
\text { attract fish (herring) to light }\end{array}$ & $\begin{array}{l}\text { Light incandescent bulb of different watt } \\
\text { employed }\end{array}$ & $\begin{array}{c}\text { Immature herring kept in separate fiberglass } \\
\text { tanks with suspended incandescent lamp that } \\
\text { provided illumination }\end{array}$ & $\begin{array}{l}\text { Adjustment of light intensity based on light source } \\
\text { distance and illumination of meter candles; } \\
\text { Conducted trials compared scores statistically. }\end{array}$ \\
\hline $\begin{array}{l}\text { Varanelli and } \\
\text { McCleave [43] }\end{array}$ & $\begin{array}{l}\text { Fish locomotor activity light cycle } \\
\text { rhythms by natural day length, } \\
\text { constant light/darkness, as well as } \\
\text { 6-hour shift light cycles } \\
\end{array}$ & $\begin{array}{l}\text { Light tight water baths affixed with } 20 \mathrm{~W} \\
\text { fluorescents }\end{array}$ & $\begin{array}{l}\text { Fluorescent light per water bath controlled by } \\
\text { time clocks set at natural light cycles as } \\
\text { average sunrise and sunset times }\end{array}$ & $\begin{array}{l}\text { Temperature maintained water baths; } \\
\text { Simultaneous fish/visual observations of locomotion; }\end{array}$ \\
\hline Yang [44\&54] & $\begin{array}{l}\text { Light intensity (day/night times) } \\
\text { inducing maximum gathering rate of } \\
\text { two fish species }\end{array}$ & $\begin{array}{l}\text { Combination of } 5 \mathrm{~W} \text { and } 150 \mathrm{~W} \text { light bulbs, } \\
\text { six artificial light sources and } 7 \text { filters }\end{array}$ & $\begin{array}{l}\text { Marbled sole and rock trout used; } \\
\text { Depth maintained at } 50 \mathrm{~cm} \text { level, the water } \\
\text { tank set in dark room illuminated at one end } \\
\text { to control horizontal light intensity. }\end{array}$ & $\begin{array}{l}\text { Tank marked into } 6 \text { longitudinal sections } 60 \mathrm{~cm} \text { length } \\
\text { to allow for fish distribution and observation }\end{array}$ \\
\hline Higgs and Fuiman [30] & $\begin{array}{l}\text { Light intensity effect on schooling in } \\
\text { gulf Menhaden larva by } \\
\text { (retino-motor/behavior) movement }\end{array}$ & $\begin{array}{l}\text { Light tight room of infra-red(IR) light and } \\
\text { incandescent bulb, }\end{array}$ & $\begin{array}{l}475 \text { gulf Menhaden larva collected by dip net } \\
\text { of boat basin; } \\
\text { Fish samples kept in } 150 \mathrm{~L} \text { seawater in light } \\
\text { blue cylindrical tank. }\end{array}$ & $\begin{array}{l}\text { Light intensity determined using underwater spherical } \\
\text { quantum sensor; } \\
\text { Schooling behavior detected by computerized } \\
\text { image-analysis system. }\end{array}$ \\
\hline Ryer and Olla [28] & $\begin{array}{l}\text { Role of light in foraging of two } \\
\text { pelagic juvenile fish species (walleye } \\
\text { Pollock and sable fish) }\end{array}$ & $\begin{array}{l}\text { 60W light emitted diode (LED) infrared } \\
\text { (IR) illuminator of wavelength } 760-880 \mathrm{~nm}\end{array}$ & $\begin{array}{l}\text { Juveniles maintained in identical glass } \\
\text { drainable tanks with resembling water } \\
\text { conditions, equipped with feed tubes }\end{array}$ & $\begin{array}{l}\text { Light measurements employed IL } 1700 \text { Research } \\
\text { Radiometer with specific illumination adjustments; } \\
\text { General experimental protocols followed with light } \\
\text { variations. }\end{array}$ \\
\hline Ryer and Olla [29] & $\begin{array}{l}\text { Juvenile walleye Pollock response to } \\
\text { net panel approach under various } \\
\text { light regimes }\end{array}$ & $\begin{array}{l}\text { Fish behavior/ response to darkness }(<1 \mathrm{x} \\
\left.10^{-8} \mu \text { moles photons } \mathrm{m}^{-2} \mathrm{~s}^{-1}\right) \text { and light }(1.7 \mathrm{x} \\
\left.10^{-3} \mu \text { moles photons } \mathrm{m}^{-2} \mathrm{~s}^{-1}\right) \text { intensities; } \\
\text { Net panel behavior response to six } \\
\text { illuminations ranged to encompass visual } \\
\text { response threshold of inspected species to } \\
\text { approaching gear. }\end{array}$ & $\begin{array}{l}\text { Sampling conducted by light suspension } \\
\text { above water surface at night; } \\
340 \text { L rectangular fiberglass tank using } \\
\text { continuous flowing seawater }\end{array}$ & $\begin{array}{l}\text { Overhead video camera system employed; } \\
\text { Tank equipped with plexiglass frame supported by } \\
\text { mesh panel of square poly material. }\end{array}$ \\
\hline Marchesan, et al. [13] & $\begin{array}{l}\text { Behaviors of four different fish } \\
\text { species exposed to artificial lights } \\
\text { based on selective fishing methods }\end{array}$ & $\begin{array}{l}\text { Halogen lamp set at } 8 \text { levels of increasing } \\
\text { illumination } 1 \mathrm{~m} \text { from undercover tank; } \\
\text { Light intensity set within limit tolerance } \\
\text { range with color visual spectra allowance }\end{array}$ & $\begin{array}{c}700 \mathrm{~L} \text { rectangular fiberglass tank with } \\
\text { transparent window uncovered during } \\
\text { experiments }\end{array}$ & $\begin{array}{c}\text { One year experimental activity at one location; } \\
\text { Video camera employed. }\end{array}$ \\
\hline Liao et al $[8]$ & $\begin{array}{l}\text { Using different selected light } \\
\text { intensities to fish target species by } \\
\text { stick-held net fishing vessels }\end{array}$ & $\begin{array}{l}\text { Two } 12 \mathrm{~kW} \text { underwater halogen bulbs } \\
\text { interchangeably combined with six different } \\
\text { deck light intensities }\end{array}$ & $\begin{array}{l}\text { Underwater illumination measured by } \\
\text { underwater photometer; } \\
\text { Catch duration of } 120 \mathrm{~min}\end{array}$ & $\begin{array}{c}\text { In-situ experiments conducted; } \\
\text { Catch analysis by body length, weight and weight } \\
\text { composition, catch per unit effort (CPUE) as well as } \\
\text { fishing frequency }\end{array}$ \\
\hline Marchesan et al. [34] & $\begin{array}{c}\text { Aggregation, phototaxis and } \\
\text { photokinesis of fish species affected } \\
\text { by light intensity as well as } \\
\text { wavelength of artificial lights }\end{array}$ & $\begin{array}{l}\text { Lamps with eight increasing illumination } \\
\text { levels, with light intensity within range limit } \\
\text { range of fish tolerance to allow for color of } \\
\text { visual spectrum }\end{array}$ & $\begin{array}{c}\text { Fish kept in } 700 \mathrm{~L} \text { rectangular tank with } \\
\text { transparent glass window uncovered during } \\
\text { experiment; } \\
\text { Tank divided into five sections based on light } \\
\text { source distance }\end{array}$ & $\begin{array}{c}\text { One year experimental activity at one location; } \\
\text { Video camera employed }\end{array}$ \\
\hline Meager et al. [56] & Influence of light intensity on visually & Light indirect illumination of 150 and 500 & Experimental set-up involved large glass & Prior to experiment, samples were starved (4-5 days) \\
\hline
\end{tabular}




\begin{tabular}{|c|c|c|c|c|}
\hline & $\begin{array}{l}\text { mediated foraging of juvenile cod and } \\
\text { relationship between light intensity } \\
\text { and visual reactive distance }\end{array}$ & $\begin{array}{l}\text { W halogen flood lights combined } \\
\text { differently; Halogen lights directed toward } \\
\text { white walls and ceiling of room. }\end{array}$ & $\begin{array}{l}\text { aquarium with acclimatization and prey } \\
\text { compartments; Prey cylinders made of } \\
\text { polyvinyl chloride enabled non-distortion of } \\
\text { visual image of prey. }\end{array}$ & $\begin{array}{l}\text { followed by overnight acclimatization; Statistical } \\
\text { analyses employed analysis of variance (ANOVA) }\end{array}$ \\
\hline Owino et al. [46] & $\begin{array}{l}\text { Design and construct of fishing light } \\
\text { attractor by determination of best } \\
\text { color }\end{array}$ & $\begin{array}{l}\text { Light colors tested include red, blue, yellow } \\
\text { and white }\end{array}$ & Experiments conducted in transparent tank & $\begin{array}{l}\text { Two types of fry and fingerling fish sizes between } \\
\text { 3-7cm were used; } \\
\text { Tilapia and gold fish were obtained }\end{array}$ \\
\hline Bryhn et al. [57] & $\begin{array}{c}\text { To compare catch (CPUE) and } \\
\text { biomass (WPUE) of Atlantic cod in } \\
\text { two-chambered floating cod pots } \\
\text { with/without green lamp as a form of } \\
\text { visual stimuli }\end{array}$ & $\begin{array}{c}\text { Green lamps of LED type with peak } \\
\text { wavelength of } 523 \mathrm{~nm} \text { and maximum output } \\
\text { intensity of } 124 \mathrm{uW}\end{array}$ & $\begin{array}{l}\text { Experimental field fishing with control pots } \\
\text { and pots modified with green underwater } \\
\text { lamps }\end{array}$ & $\begin{array}{l}\text { Non-parametric Mann-Whitney U test to compare } \\
\text { CPUE and WPUE between control and experimental } \\
\text { pots, as well as stepwise multiple regression to } \\
\text { establish the determinants of CPUE and WPUE }\end{array}$ \\
\hline Hannah et al. [58] & $\begin{array}{l}\text { To determine how addition of } \\
\text { artificial light in the vicinity of } \\
\text { rigid-grate by-catch reduction device } \\
\text { (BRD) along fishing line of ocean } \\
\text { shrimp trawl altered fish bycatch and } \\
\text { ocean shrimp catch }\end{array}$ & $\begin{array}{l}\text { 1-4 Lindgren Pitman Electralume } 囚 \text { LED } \\
\text { lights (green/blue) in locations around the } \\
\text { rigid-grate BRD and } 10 \text { green lights along } \\
\text { the trawl fishing line }\end{array}$ & $\begin{array}{l}\text { Double-rigid shrimp nets employed with one } \\
\text { net incorporating artificial lights and other to } \\
\text { serve as control; Both experiments conducted } \\
\text { with rigid-grate BRDs with } 19.1 \mathrm{~mm} \text { bar } \\
\text { spacing installed at each net }\end{array}$ & $\begin{array}{l}\text { Light levels inside the net were measured using } \\
\text { Wildlife Computers TDR-Mka archival tags } \\
\text { (calibrated using International Light IL } 1700 \text { light } \\
\text { meter and PAR sensor) }\end{array}$ \\
\hline
\end{tabular}


Catching the Fish with Light: Experimental Methods and Instrumentation

Thus far in this work, light is shown to occupy an important place in the visual capability of fish species. Because the light and dark fishing tows may seem rather demanding to replicate, how differences in either tow depth or position influence observed fish behaviour [36] is therefore needful to consider. In that both laboratory and field-based results complements one another would suggest how reliable light dependent effects actually can be. Given this abovementioned context(s), differences in trawl conditions is inevitable when comparing laboratory and field situations. This probably would be owed to differences in contrasts/forms of trawl, angle(s) of illumination as well as bioluminescence. Further, the gear modifications that target the visual responses of fish species even at night times and by depth have not always been so successful [36]. Some evidenced methodologies used by different light-fish studies and corresponding experimental set-up are summarized in
Table 3. Synthesizing these evidences, themes deduced include differences in light intensities, the different (artificial) light exposures, the (attractive) function of light, as well as light cycles/regimes. In fact, to operably connect the respective experimental set-ups with above themes would depend on the available (on-site) resources of these conducted studies, which may well corroborate with the corresponding lighting features. For example, earlier authors $[4,42]$ both employed bulbs of different watt for attracted illumination, wherein re-circulation of dissolved oxygen in tank specifically allowed for light intensity adjustments based on light source distance(s) and illumination candle meter, which allowed for some differentiation of this given parameter, as depicted in Fig. 2. The light -dependent behavioural pattern of fish using the different colour filters allowed for determination of light intensity measurement thresholds. The spectral sensitivity curves allowed for plot the $\log _{10}$ reciprocal of light threshold against the peak wavelengths [42].

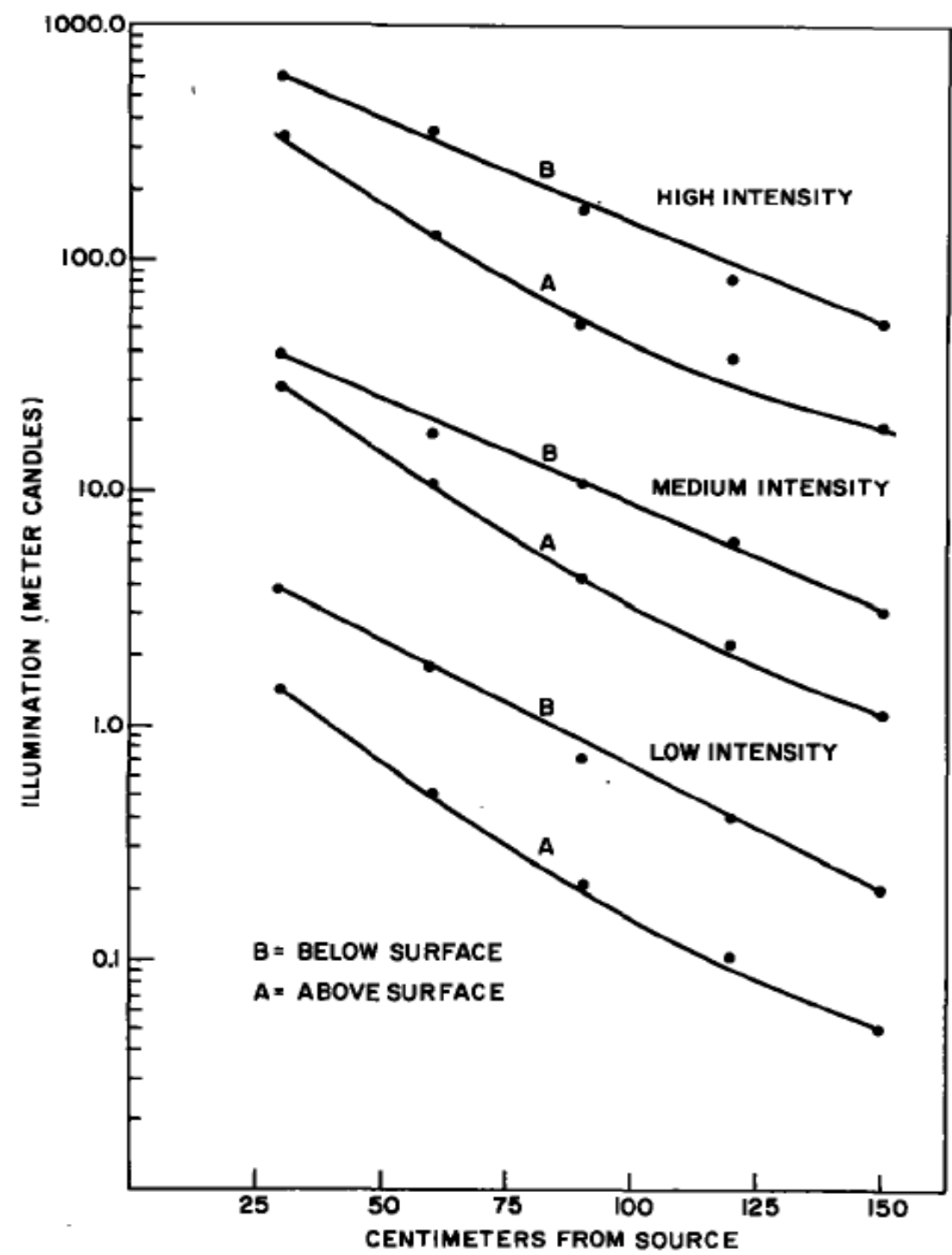

Figure 2. Light gradients at three light intensities as reported by Stickney [4]. 
Consistent with techno-advances, other light features as well as experimental set-ups developed/evolved. For example, Varanelli et al. [43] experimented with the $20 \mathrm{~W}$ fluorescent to light-up water baths under controlled time set as natural light cycles of (mean) sunrise and sunset times coincidental with light cycles of natural day length, constant light/darkness as well as 6 hour shift light cycles. Yang [44] combined two $5 \mathrm{~W}$ and $150 \mathrm{~W}$ light bulbs, six artificial light sources and 7 filters all in dark room situation using illumination system that attracted at one end and controlled by horizontal light intensity. Notable light and fish-related researches have involved fish response to light and dark conditions $[16,18,29,36]$, increases and decreases in light intensities (measured in $\mu$ mol photons $\mathrm{m}^{-2} \mathrm{~s}^{-1}$ ) $[8,13,34,39$, $41,45]$, the use of lighting systems either solely or combined such as halogen bulbs/lamps [8, 27, 34], incandescence and halogen, metallic iodide [27], different light colours such as blue, red, white and yellow [46], infrared (IR) light emitting diode (LED) lamps [16] as well as IR working together with incandescent bulb [30].

The insensitivity to IR light varies among fish species. For example, wavelength of between $760-880 \mathrm{~nm}$ has been used to assess fish behaviour under IR illumination as well as low visible light conditions $[28,30]$. Specifically in a light-tight room of infrared (IR) light and incandescent bulb, the latter that produced light through a diffuser before it would reach the water surface, Higgs and Fuiman [30] employed light blue colour for tank. In order to study the role of light in the foraging behaviour of two inspected pelagic juvenile species, Ryer and Olla [28] employed 60W LED IR illuminator in glass drainable tank that allowed for haphazard selection of different light levels in the tank. Given that some authors consider fish behaviour as light dependent, the avoidance behaviour can therefore be inhibited when light is inadequate, which probably accounts for the diverse reactions (by fish) to artificial/natural light exposure [24, 34]. Bradburn and Keller [37] indicated that when any given disturbance approaches, the fish would typically effort to maintain some ample distance and only to react in response to the perceived probability of catch and within the effective area/volume. Olla et al. [35] understood that the uses of sensitive IR illumination and video cameras could improve the observation success of fish behaviour particularly in the darkness situations. In addition, video observations as well as utilization of trawl bags can strengthen observing the fish as it passes beneath the trawl lines, either being rolled over by bottom gear as the herd opportunistically escapes through gaps found between ground gear and bottom of given trawl [16]. Techno-advances have made high definition (HD) video cameras of high quality and robust pixel capacities very handy to offer better/improved image analysis/precision, which can also be accompanied/connected with either
iPhone and or other related/similar mobile devices to facilitate the image handling, processing up to its transfer.

To effectively compare some experimented lighting-fishing instrumentation(s) would require comparisons of laboratory results with real-time/field situation(s). Fig. 3(A) shows single (a) and double (b) tanks illuminated by light from the side employed by Blaxter [42] that purposed to describe the measurements of spectral sensitivity. Fig. 3 (B) shows the net towing apparatus and tow tank employed by Olla et al. [18] that had purposed to investigate the role of light intensity as affected by simulated trawling of some fish species. Fig. 3 (C) shows the schematic diagram of experimental tank and equipment employed by Gabr et al. [39] during a trawling experiment conducted in circular water tank purposed to assess the effects of light intensity on active escape of undersized fish. From Fig. 3(A), Blaxter [42] constructed the tank in such a way that both had translucent screens to allow for light passage, and for the double tank, a white reflector placed somewhat adjacent to the black plastic netting. From Fig. 3 (B), Olla et al. [18] employed twin net towed apparatus already designed to simulate various trawling speeds in cod-ends of fishing trawl to induce stress on the inspected samples. Different from Blaxter [42], the work of Olla et al. [18] allowed for seawater supply into the system, as the circular pool would follow the net tow. The cylindrical test nets shown therein would be fastened with the nylon diamond net that comprised of both aluminium hoop and flap. The twin nets would be purposed to maintain the hydrodynamic balance of the towing apparatus. The rigid baffre panels with the mesh underneath each would then support the beam near the inside tank edge to help sustain the water current that had to be generated by the revolving arm/nets. Compared to the instrumentation used by Blaxter [42] (Fig. 3A) as well as Olla et al. [18] (Fig. 3B), there are such additional facilities of Gabr et al. [39] (Fig. 3C) as speed controllable motor fitted over circular tank as well as framed net set at motor arm end to rotate enhanced the trawl towing simulation. Furthermore, as the motor was set to raise and bring the net door to the water surface so as to release the fish inside the net, the wooden bars already placed on both sides of the tank would help diffuse the water flow as the framed net moved. Anteriorly and posteriorly, both blue polyethylene mesh and white nylon panel would help reduce the lighting contrasts of netting to the tank wall. With either white polyethylene square or diamond mesh installed, the middle of frame net would purpose for escape panel. In addition, the separating panel to form the boundary between the anterior and posterior spaces would allow for the better observation of fish prior to its escape. Moreover, the use of IR CCD infrared camera allowed for the real-time capture of these experimental events, which probably helped to enhance validity of generated data. 


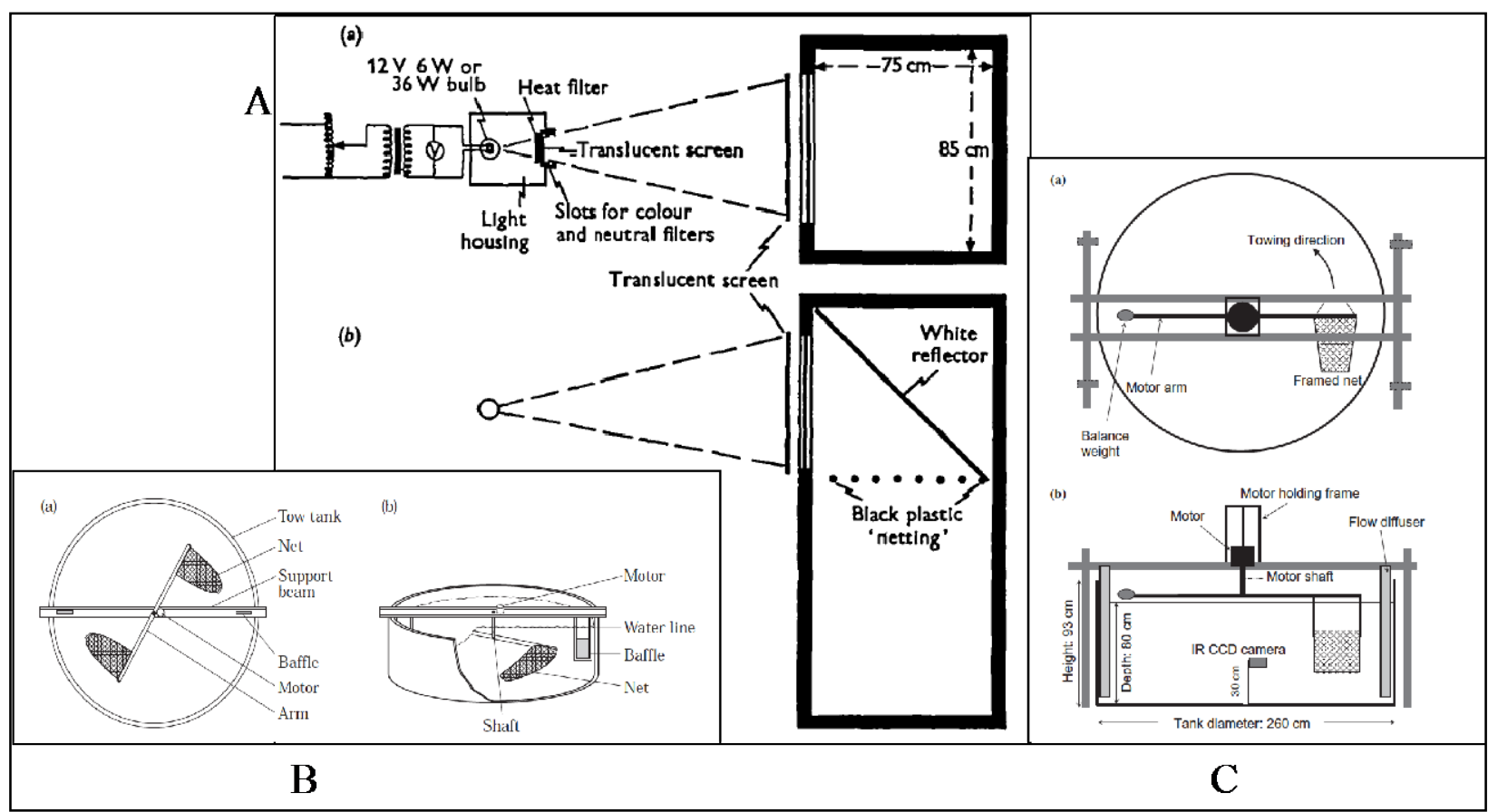

Figure 3 (A-C). Pictorial diagrams of fishing - targeted experimental situations: (A) Sourced from Blaxter [42], shows single (a) and double (b) tank types both equipped with translucent screens and the light source and type; (B) Sourced from Olla et al. [18], shows the net towing apparatus and tow tank at (a) plan (tow tank is $4.5 \mathrm{~m}$ diameter) as well as (b) cutaway elevation views. The gear reduction $90-\mathrm{V}$ DC motor was $0.5 \mathrm{hp}$ whereas the shaft and arm were stainless steel and net hoops made of aluminum; (C) Sourced from Gabr et al. [39], shows schematic drawing of experimental tank and equipment from (a) top and (b) side views depicting the infrared CCD camera.

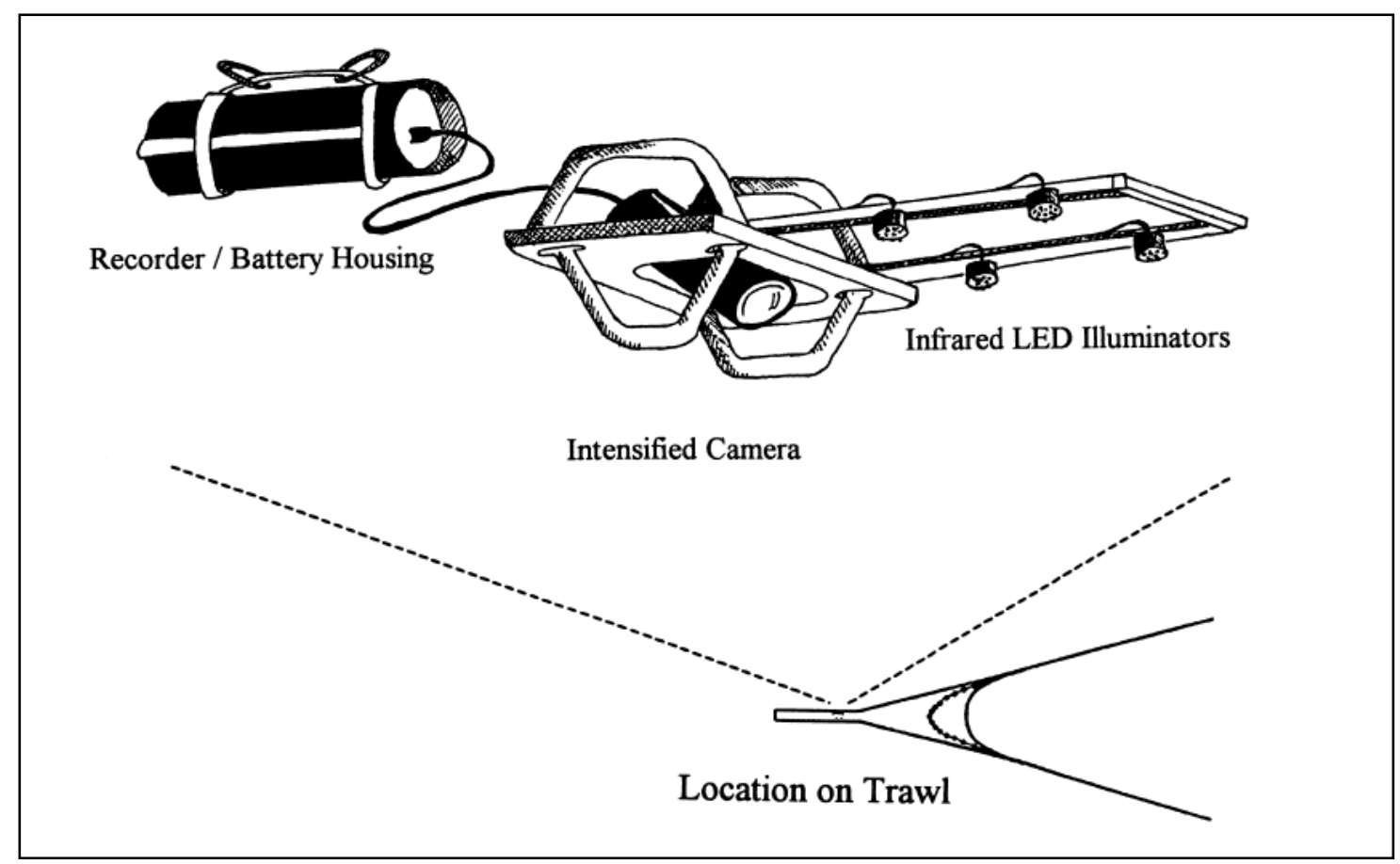

Figure 4. A schematic diagram of video recording apparatus for mounting on trawl gear, including the mounting frame, IR illuminators, IR sensitive video camera, recorder as well as battery housing, The insert shows the location of recording apparatus on the trawl (Source: Olla et al.[36]).

In line with real-time observations, Olla et al. [36] monitored the orientation/swimming of walleye Pollock in trawl net under light and dark situations using an underwater video system, depicted by Fig. 4 where water proofed video recording apparatus was mounted on trawl gear. The mounting frame, IR illuminations, IR sensitive video camera, recorder as well as battery housing can be seen also. Specifically, images of that study appeared to equal the area of near field view based on counts of net meshes. The total volume imaged would vary with visibility as function of both 
light quantity and turbidity. Playback recorder follows video of fish in trawl, with both light and dark situations analysed with time as sampled fish remained with area view. Considering the bearing angle on video screen using a protractor, the angle per fish (the head facing the mouth of trawl) that was other than normal to the trawl would also be determined. In addition, the number of fish(the head also facing the mouth of trawl) sin the video frame that swum normal to and other than normal to axis of trawl would also be counted. However, the availability of only one trial at each light and dark trawling situation can be limiting such study especially in absence of replicated field trials.

\section{Light Intensities (I): Attraction and Reaction of Fish}

Due to the spatial orientation, some fish species can swim inside the net in the dark or low light conditions [39, 47]. While the light source at night are used to attract fish [24], the use of powerful lighting for light fishery practice at coastal waters has been applied to fish species such as sardine, herring and so on [8]. In addition, the lighting-fishery studies use phototaxis approach, deck and underwater fishing lamps to attract the fish to light zone to guide them into the net $[15,48]$. While fish catch and species composition in light-fishery studies can appear complex, catch mechanisms have to be robust to improve fishery yield [8]. However, there appears to be limited understanding/lack of explanation about the visual thresholds for fish detection of trawl gear because only but few studies have considered this. Data about feeding thresholds is limited, for example those reported by Ryer and Barnett [16] about English and Northern rock sole as well as Pacific halibut, where these fish species could loose its visual ability to detect at light levels of about $5 \times 10^{-5} \mu \mathrm{mol}$ photons $\mathrm{m}^{-2} \mathrm{~s}^{-1}$.

The depth of light levels can also alter fish species-specific availability to trawl to influence catch rates $[38,49]$. Besides, the adequacy of light for visual detection may often not always account for the reason why fishing operations are commonly performed at either depths or night when the light quantity falls to below the visual capabilities of most fish species [36]. By way of astronomical and metrological conditions the quality and quantity of available light in aquatic environments have also been reported such as illumination at higher magnitude of full daylight with clear skies up to moonless nights [28]. In addition, light intensity is considered to decrease exponentially along the water column [27, 50]. Moreover, many fish species show preference to medium-to-low light with some distance from light source [34, 51]. Whereas some diurnal fish species adapt to broader light intensity range of visual spectrum with low reactivity to tolerate increase in light intensities, nocturnal types appear sensitivity to low-to-very low light sources and shorter wavelength exposures of either violet, blue and or green colours, probably presenting some reduced tolerance. Invariably, such nocturnal species may well possess rather flexible behavioural patterns [34, 52].
Also dependent on tank size, fish species like herring (Clupea harengus) would discontinue avoidance of stationary nets when light intensities range between $0.01-$ 0.0001 photopic lux [53]. Spectral sensitivity of 20 juvenile herrings to light that used different colour filters showed how such threshold light intensity decreased such abovementioned behaviour as maximum sensitivity of dark adapted samples were between $510-520 \mathrm{~m} \mu$ with threshold light intensity of between $3.6 \times 10^{-2}$ and $2.9 \times 10^{-4}$ photopic lux and somewhat dependent on existent behaviour [42]. By locomotor activity rhythms in light cycles, electro-fished (immature) Atlantic salmon parr studied elsewhere showed light-dark dependency by rhythm-activity time of $24 \mathrm{~h}$ periods. Specifically, while some inspected samples appeared nocturnal, others appeared diurnal. The six hour light cycle showed minor coordinated pattern shifts but rather less to the constant light, which appeared weaker at the constant darkness situation. Higgs and Fuiman [30] studied the retino-behaviour movement of gulf Menhanden larvae as light intensities changed up to the schooling process/stage and found that whilst the statistical angles between the inspected samples were related inversely to light intensity yet independent of direction of change of intensity, any positive movement seemed to increase as light intensity decreased.

Fish feeding primarily dependent on vision is also reflected in Pankurst and Hilder [41] that studied the effect of light intensity on feeding response of striped trumpeter larvae. The result showed that the younger the larva the lower the feeding response particularly at reduced light intensities. Feeding behaviour especially with increased light intensities seems to improve with age but at varying responses. Ryer and Olla [28] studied the effect of light on foraging of two pelagic juvenile walleye Pollock and sable fish and observed that threshold of illumination below which the fish were unable to visually forage would be $\sim 5 \times 10^{-5}$ and $\sim 5 \times 10^{-7} \mu \mathrm{Es}^{-1} \mathrm{~m}^{-2}$ for the sable fish and walleye Pollock, respectively. Even though these two species fed effectively under some light quantities well before the abovementioned threshold, both species exhibited the capacity to detect and capture prey especially at night. Ryer and Olla [29] further examined the response of juvenile walleye Pollock with respect to the approach to the net panel particularly under various light regimes and found increase in fish frequency to strike the net in the darkness situations, which suggested the potential decline in trawl by-catch reduction strategies especially if under size or non-target fish that used the vision to guide these species of the net were to be relied upon, and either at night or depths at ambient light levels. Owino et al. [46] constructed/designed workable fishing light attracter to determine the best colour that attracted fingerlings of tilapia and gold fish. Seemingly, tilapia positively favoured the blue light in somewhat linear trend as the light intensity increased. However, whilst the gold fish seemed to favour the similar direction, it was frequently fluctuated.

Interactively, light intensities can show different effects on 
fish species from juveniles up to adult situation(s). Liao et al. [8] specifically revealed this when selective light fishing intensities was applied to some targeted species. That study reported that the catch per unit effort (CPUE) would relate differently light intensity by group as accounted for different fish types and under varying light intensities. Smaller fish size types seem to favour the higher CPUE, specific to lower light intensity (below 40kW) compared with those of higher intensity (above 60kW) whereas the larger fish size types favoured the higher CPUE specific to those of higher light intensity. Also, the CPUE would more likely be influenced not only by some physical factors such as the capacity of fishing light, but also by some biological factors such as the presence of predator, size and so on. Besides, Yang [54] investigated how light intensity would induce the maximum gathering rate of either marble sole and or rock trout at daytime and night and found that light intensity would induce the maximum gathering rate of 1.9 lux (1.2 2.9 lux) at daytime and 0.7 lux $(0.5 \sim 1.1$ lux $)$ at night-time for sole and 0.7 lux (0.5 1.1 lux) and 5.2 lux (3.2 7.7 lux) for rock trout, respectively. Within the illumination time, the gathering rate of those inspected fish samples inconsistently reduced yet comparatively although with rather stable trend(s).

Ciriaco et al. [27] found that fish species such as sea bass, common grey mullet and seam beam in reacting to artificial light responded actively to light intensity variations but to some degree by differing light colours. At sea bass for example, there were increased effects at the shorter light wavelengths of blue/green + aggregation towards activity inhibition that negated phototaxis. The behavioural reactions (of fish species) could be accounted for by light intensity variations because sea bass, for example, responded more to progressive decreases in light intensity given its aggregation at lower activity level. Marchesan et al. [13] examined the behaviour of four different fishery species (Dicentrarchus labrax, Mugil cephalus, Sparus auratus, and Lithognathus mormyrus) by selective fishing methods under exposure of some artificial lights and found inspected $S$. auratus and $M$. cephalus highly light attracted whereas D. labrax seemed rather unaffected. But $L$. mormyrus would get attracted to all the tested light intensities. Based on the studied wavelengths, while $M$. cephalus appeared more responsive to monochromatic short wavelength stimuli and D. labrax appeared similarly perceptible, $S$ auratus showed some repulsion whereas $L$. mormyrus remained unaffected. On the fish visual behaviour, artificial lighting could additionally contribute to some ecological classification of the inspected samples, which may well apply to other fishery species/products of economic importance/value [13]. Some authorities of fishery sciences consider it is inappropriate to identify with optimal fishing light intensity for single fish species as the basis for fishery management. Adjusting fishing light intensity on target species is therefore warranted in view to reduce the problems associated with both by-catch mortality and disturbance of the underwater environment [13].

Generally, the levels of aggregation and attraction to light can vary among fish species. Such differences might be related to some ecological, physical, phylogenetic factors as well as physical characteristics of light especially intensities $[8,29,34,36,55]$. Studying the aggregation, phototaxis and photokinesis of fish species (Chromis chromis, Sciaena umbra, Symphodus tinca and Diplodus sargus) and its response to different light intensity as well as wavelengths of artificial lights, Marchesen et al. [34] found that whilst fish groups would continue to aggregate independent of varying light intensities, only but a few may strongly react to the illuminated fields. For instance, whilst C. chromis appear moderately affected by changing light intensity especially with strong lighting and $S$. tinca appear only but slight affected, those of $D$. sargus would moderately aggregate although not so pronounced as it would actively keep some distance from the light source. Meager et al. [56] examined the influence of light intensity on visually mediated foraging of juvenile cod and used predictive visual model(s) to understand how light intensity related with visual reactive distance, wherein visual reactive distance was determined at five light intensity levels $(0.01,1.6,6.5,29$ and $64 \mu \mathrm{mol}$ $\left.\mathrm{m}^{-2} \mathrm{~s}^{-1}\right)$. The changes in irradiance that could be encountered in natural habitats based on the fitted visual model are showed in Fig. 5. The reactive distance found at $0.1 \mu \mathrm{mol}$ $\mathrm{m}^{-2} \mathrm{~s}^{-1}$ indicated a high sensitivity to low light level situation. The reactive distance specifically appeared less at intermediate light levels ( 6.5 up to $\left.29 \mu \mathrm{mol} \mathrm{m} \mathrm{m}^{-2} \mathrm{~s}^{-1}\right)$ but with some increases, thereafter. In addition, how the fish responded to prey seemed not significantly associated with light intensity. Further, the reactive distance may well be reduced at the intermediate light intensity irradiance of between 6 and $29 \mu \mathrm{mol} \mathrm{m} \mathrm{m}^{-2} \mathrm{~s}^{-1}$, which probably arose as forage behaviour varied with (different) light intensities. In fact, the distance at which the fish would see a prey (sighting distance) and that which to react to a prey (reactive distance) can vary with foraging mode, with sighting distance above that of reactive when fish pause-travel search, but could strike a balance at cruise search as well [56]. It is important to reiterate that Meager et al. [56] further indicated colour, view angle and angular distribution of light were among factors that should be built into the development of visual models. 


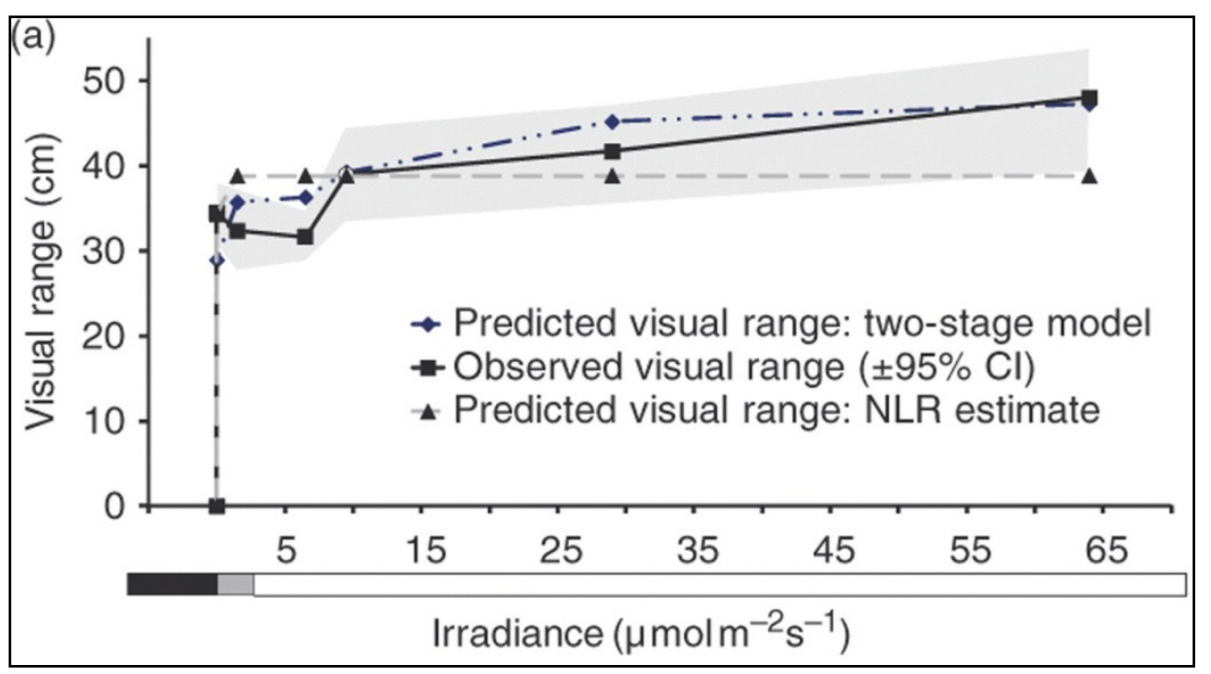

Figure 5. The fit of visual model of experimental data (squares) sourced from Meagres et al. [56] where the predicted values have been based on the two-stage model.

Table 4. Comparison of mean catch by species or group (weight, $\mathrm{kg} \mathrm{haul}^{-1}$ except for darkblotched rockfish, other juvenile rockfishes and other small flatfish, which are expressed as $\mathrm{g} \mathrm{haul}^{-1}$ ) between ocean shrimp trawl nets equipped with artificial LED lights attached to the fishing line (at the footrope, see text) and a control net with no lights. Species were captured off the Oregon coast in 42 hauls employing double-rigged nets, one incorporating the artificial lights, during July 2014. (Source: Hannah et al., [58])

\begin{tabular}{|c|c|c|c|c|}
\hline \multirow{2}{*}{ Species or group } & Artificial lights & Control net (no lights) & \multirow{2}{*}{ Percent reduction with lights (\%) } & \multirow{2}{*}{$P$-value* } \\
\cline { 2 - 5 } & Mean catch (SE) & Mean catch (SE) & 0.7 & $\mathrm{~ns}$ \\
\hline Ocean shrimp (Pandalus spp.) & $203.68(24.19)$ & $2015.15(23.69)$ & 90.5 & 0.0001 \\
\hline Pacific eulachon (Thaleichthys spp.) & $1.12(0.20)$ & $11.77(1.68)$ & 68.6 & 0.0001 \\
\hline Slender sole (Lyopsetta spp.) & $0.72(0.17)$ & $2.29(0.35)$ & 69.4 & 0.0001 \\
\hline Other small flatfish & $171.18(28.24)$ & $559.97(60.25)$ & 82.2 & 0.0001 \\
\hline Darkblotched rockfish (Sebastes spp.) & $95.44(21.63)$ & $537.23(91.01)$ & 56.3 & 0.0004 \\
\hline Other juvenile rockfish (Sebastes spp.) & $55.09(22.40)$ & $126.13(29.73)$ & & \\
\hline
\end{tabular}

Key: ns = non-significant; SE (standard error); $(*)=3$ factor ANOVA

Bryhn et al. [57] compared the catch (CPUE) and weight per unit efforts (WPUE) of Atlantic cod using visual stimuli of green lamps in two-chambered floating cod pots and found that the green lamp inside the pot increased both CPUE and WPUE of cod above the maximum legal size $(>38 \mathrm{~cm})$ by 74 and $80 \%$, respectively. However, CPUE and WPUE did not change at small $(<38 \mathrm{~cm})$ cod caught in pots with/without the green lamps. Also, increasing catch efficiency of cod green lamps was deemed to benefit the Baltic commercial cod pot fish industry. Hannah et al. [58] studied the effect of adding artificial light in vicinity of rigid-grate bycatch reduction device (BRD) along the fishing line of ocean shrimp trawl on both fish and ocean shrimp bycatch through the investigated (12) paired hauls. Contrary to the expectations of these authors, adding artificial light around rigid grate would increase bycatch of such fish species as eulachon by $104 \%(\mathrm{P}=0.0005$, by weight $)$ and slender sole by $77 \%(\mathrm{P}=0.0082)$, but no effect on either ocean shrimp and or bycatch of other fishes $(\mathrm{P}>0.05)$. The addition of 10 LED lights along the fish lines would markedly reduce wide variety of fish bycatch without affecting the ocean shrimp catch $(\mathrm{P}>0.05)$. In fact, bycatch reductions recorded were as follows: eulachon by $91 \%$
( $\mathrm{P}=0.0001)$, slender sole and other small flatfishes by $69 \%$ $(\mathrm{P}<0.0005)$, darkblotched rockfish by $82 \%(\mathrm{P}=0.0001)$ and juvenile rockfish by $56 \%(\mathrm{P}=0.0001)$ (Table 4). Hannah et al. [58] further mentioned that adding artificial light resulted in such fish behavioural differences. The bycatch reduction still remain unexplained although artificial light greatly increases fish passage through restricted spaces, which typically would not readily pass through even under the ambient light situation(s) of normal seafloor.

\section{Light Intensities (II): Active Escape of Fish}

Majority if not all fish species, would make effort to avoid any given net(s) obstruction [39, 59-60]. Most likely, fish would be hesitant to pass through the net even when there is ample space. Usually, many fish species strive for successful escape when stimulated either visually and or otherwise. For example, fish escape frequency away from any given square mesh panel can increase by the creation of visual illusion using black tunnel in the cod end extension [59-60]. Vision thus occupies an important place/position in active escape of fish [39]. Many fish species however might not be able swim in a uniform manner toward the net and maintain a good 
position within the trawl at the same time, even under the light and dark situations [36, 39, 61]. The understanding that some juvenile fish species would be affected by the light intensity during the active escape, justifies Gabr et al. [39] studies of fish samples that possessed high swimming capabilities (using a rectangular tank). Kept at the posterior part of net separated from anterior prior to the commencement of that experimental trial and using waterproof color IR CCD camera, Gabr et al. [39] monitored/quantified fish movement(s) as light intensity noticeably affected fish escape through the mesh. Increase in light intensity can improve escape of fish even at lower towing speeds. However, the light conditions might not be able to improve escape of fish even at increased towing speeds. Also, mesh types might not always significantly affect the light intensity [39].

Besides, Ryer and Barnett [16] revealed that flat fish could rise/hop off from the bottom even in the darkness situations perceived as startle response that when elicited in the absence of any visual input results in an upward trajectory off the bottom within the contained habitat, which suggests important implications for the catchability of such fish species at different ambient illuminations. Such may also be largely dependent on some factors such as time of day, meteorological conditions, depth as well as turbidity [16]. Hannah and Jones [62] evaluated the behavioural impairment of escape fish species such as eulachon, which allowed for effectiveness testing of bycatch reduction facilities. The escape behaviour of eulachon species from shrimp trawl via BRD could exclude samples that actively swam in such a manner mostly to avoid any contact with rigid grate (BRD). All abovementioned were observed using underwater video and bright artificial lighting. Importantly, the potential of artificial lighting to impact on escape behaviour of eulachon species seemed apparent. Under actual fishing conditions, the exclusion efficiency of eulachon species seemed to improve as rigid-grate visibility enhanced with artificial light as video showed eulachon species avoiding the illuminated rigid grates BRD [62].

\section{Light Intensities (III): Induced Stress of Fish}

Both fish survivors and escapees may well be subject to wide range of stressors that either may and or may not result in the eventual mortality. Perchance mortality eventually occur, such might then be owed to either some physical damage or impairment of behavioural capabilities of fish to perform the critical tasks for example, food acquisition and predator avoidance. Besides, stressors may arise from such factors as fishing methods, gear type and species hardiness [18, 63-64]. Based on such established behavioural norms already reported at many fish species, the measurement of stress-induced situation(s) among sensitive and eco-pertinent yardstick employed for stress assessment and its effects and for prediction of eventual mortality [65-67]. Notably, the stress induced by both injury and physical exercise to fish can result in some physiological differences, but might not necessarily lead to eventual mortality $[18,68]$. In particular, Olla et al. [18] evaluating stress effects on feeding and predator behaviour of some fish species showed the light level detectability and swimming capabilities during both light and dark situation(s). By determining the threshold net speed at which the swimming ceased especially under the light situation, these authors found that between the inspected fish species, the net entrainment resistance varied with stress severity whereas recovery potential seemed somewhat dependent on light intensity. There appears good agreement among authors [34, 69] that the disturbance source to fish communities could equally associate with athrophic activities that concentrate along coast areas that may well pose more sensitive coastal effects, which makes routine assessment of existent coastal fisheries very essential.

\section{Simulated Trawls and Conducted Surveys}

Fish-light lab experimented studies have always purposed to exemplify/simulate the real-time field situation(s). By simulated trawl, Olla et al. [36] determined the orientation/swimming capabilities of walleye Pollock and were able to monitor the fish species as it actively swam and oriented parallel to principle axis of trawl under light conditions using underwater video system ("Refer to Fig. 4"). However, the dark situation(s) seemed to produce little-to-no active swimming effects, even though a few noticeably deviated from the principle axis of trawl. How light quantity measurement in field studies related to by-catch processes/mortality was well exemplified. Indeed, vision clearly occupies a very important place/position in trawl gear interactions for the walleye Pollock and applicable to other economically important related fish species.

Hannah et al. [58] indicated the use of colour/artificial light equally could potentially change fish behaviour as it either approaches the and or simulated by trawl. Using footrope, Ryer and Barnett [16] examined the behaviour of disturbance and herding of English and northern-rock sole as well as Pacific halibut at both light and dark situations by way of simulated trawl and observed by video system. The disturbance response found some decline starting from the light up to darkness situation(s) as fish slowly arose from bottom to allow footrope to quickly pass underneath. The behaviour patterns between these inspected species seemed much less at the night situation, which suggested some by-catch reduction avenues. Level of light intensity, number of fish species present and interaction between existent surrounding factors seemed not to profoundly affect either of the inspected species. This simulation trawl study outcomes of Ryer and Bannett [16] somewhat differed with the simulated towing effect outcome of Olla et al. [18] whereby at light intensity simulated as daylight and depth in clear ocean water $\left(0.5 \mu \mathrm{mol}\right.$ photons $\left.\mathrm{m}^{-2} \mathrm{~s}^{-1}\right)$, the walleye Pollock juvenile potentially maintained considerable swimming 
capability within the nets towed at $0.65 \mathrm{~ms}^{-1}$ for $3 \mathrm{~h}$ with zero mortality. Juveniles so active would be attributed possibly to previous stress-induction, which appears in contrast to those of English/northern-rock and Pacific halibut herein above-mentioned already.

Because fish available to survey gear associate with the overall catchability, many researchers have taken keen interest to perform assessment surveys of either extant stock or data. Apart from the vertical distribution of fish in water column to determine the proportion of available population in survey trawl, diel changes in light level can potentially affect the vertical distribution and catchability [49, 70-71]. However, in that explanatory data might help to reduce possible bias as well as improve the reliability of survey estimates of fish abundance, previous surveys have been largely performed during the daylight hours [72-73]. To test if the day time near-bottom light intensity affects the proportion of walleye Pollock's availability to bottom trawl (BT) survey, Kotwicki et al. [72] performed BT survey of light data obtained from 393 stations in 2004, 346 in 2005 and 448 in 2006 wherein the variability of light intensity by distribution functions were considered using Raster maps. Previous research on pollock's visual behaviour thresholds inspired these authors to evaluate daytime variability using on-bottom light levels. Fig. 5 shows the light-intensity thresholds known to affect Pollock visually mediated behaviour, which were based on lab-based experiments that examined the light-related changes in Pollock behaviour either in a given towed trawl $[18,36,74]$, during feeding [28, 75] and or during schooling [35]. In particular, Kotwicki et al. [72] assumed that, although the above-cited studies had been conducted on the juvenile Pollock that had light-level thresholds rather different compared to adults, the visual stimuli effect comparing adults and juvenile fish samples would still resemble. Furthermore, Kotwicki et al. [72] demonstrated that more of the walleye Pollocks seemed available at BT surveys under both high illumination and shallow depths. While the light intensity and depth would potentially influence the abundance estimates and rather dependent on the daytime survey catchability (for these inspected species), the incorporation of light measurements is a useful candidate to improve the precision of abundance estimates of these demersal species.

Bradburn and Keller [37] examined the influence of light on the catch of demersal fish species, with focused on 1380 hauls sampling confined to near-bottom daylight limited to depth of less than $400 \mathrm{~m}$, which the authors had termed as 'Relative Downward Irradiance'. Since the light and catch measurements, as was in that specific scenario, appeared not normally distributed, these authors then $\log _{10}$ transformed their resultant data in order to allow for the data predictors to meet up with the prerequisite assumption(s) of linear regression statistic. The results showed that the near bottom light and CPUE $\left(\mathrm{kg} \cdot \mathrm{ha}^{-1}\right)$ related linearly and significantly as had been given by decrease in CPUE per $\log _{10}$ light increase. Furthermore, Table 5 summarizes the linear models that Bradburn and Keller [37] had used to describe the relationships between CPUE $\left(\mathrm{kg} \cdot \mathrm{ha}^{-1}\right), \log _{10}$ light $\left(\mu \mathrm{Em}^{-2} \mathrm{~s}^{-1}\right)$, latitude $(\mathrm{N})$, and depth $(\mathrm{m})$ for arrowtooth flounder, greenstriped rockfish, longnose skate, and Pacific hake. These authors showed that while the p-values all appeared statistically significant between range of $<0.01$ up to $<0.0001$ having 'depth' of somewhat lesser effects, the light, depth and latitude was generally able to explain the variance of between $15-47 \%$ of CPUE for the inspected fish species. In addition, the probability to catch at least one fish was also determined. The probability of catch for the inspected fish species is showed in Fig. 6, where the depicted line thickness therein is proportional to mean CPUE $\left(\mathrm{kg} \cdot \mathrm{ha}^{-1}\right)$ per depth $\pm 50 \mathrm{~m}$. As the light was inversely related to the depth when it was less than $200 \mathrm{~m}$, the catch probability appeared statistically related to the light, depth, latitude as well as relative time of day for all inspected fish species. Between the $200-300 \mathrm{~m}$ depths however, the catch probability would increase with light intensity for both arrow tooth flounder and green striped rockfish. However, whereas it would decrease slightly at depths greater than $200 \mathrm{~m}$ for the Pacific hake, those of long nose skate seemed rather relatively unaffected by the light intensity at these depths. Overall, the survey trawl catch rates appeared dependent on availability of light although the light to catch rates as well as light measurements would allow for the proper interpretation of results of fisheries - independent bottom trawls and the subsequent use of trawl data in other population assessments. 
Table 5. Summary of the linear models used to describe the relationships between CPUE (kg/ha), $\log _{10} \operatorname{light}\left(\mu \mathrm{Em}^{-2} \mathrm{~s}^{-1}\right)$, latitude $(\mathrm{N})$, and depth (m) for arrowtooth flounder, greenstriped rockfish, longnose skate, and Pacific hake (Sourced from: Bradburn \& Keller, [37])

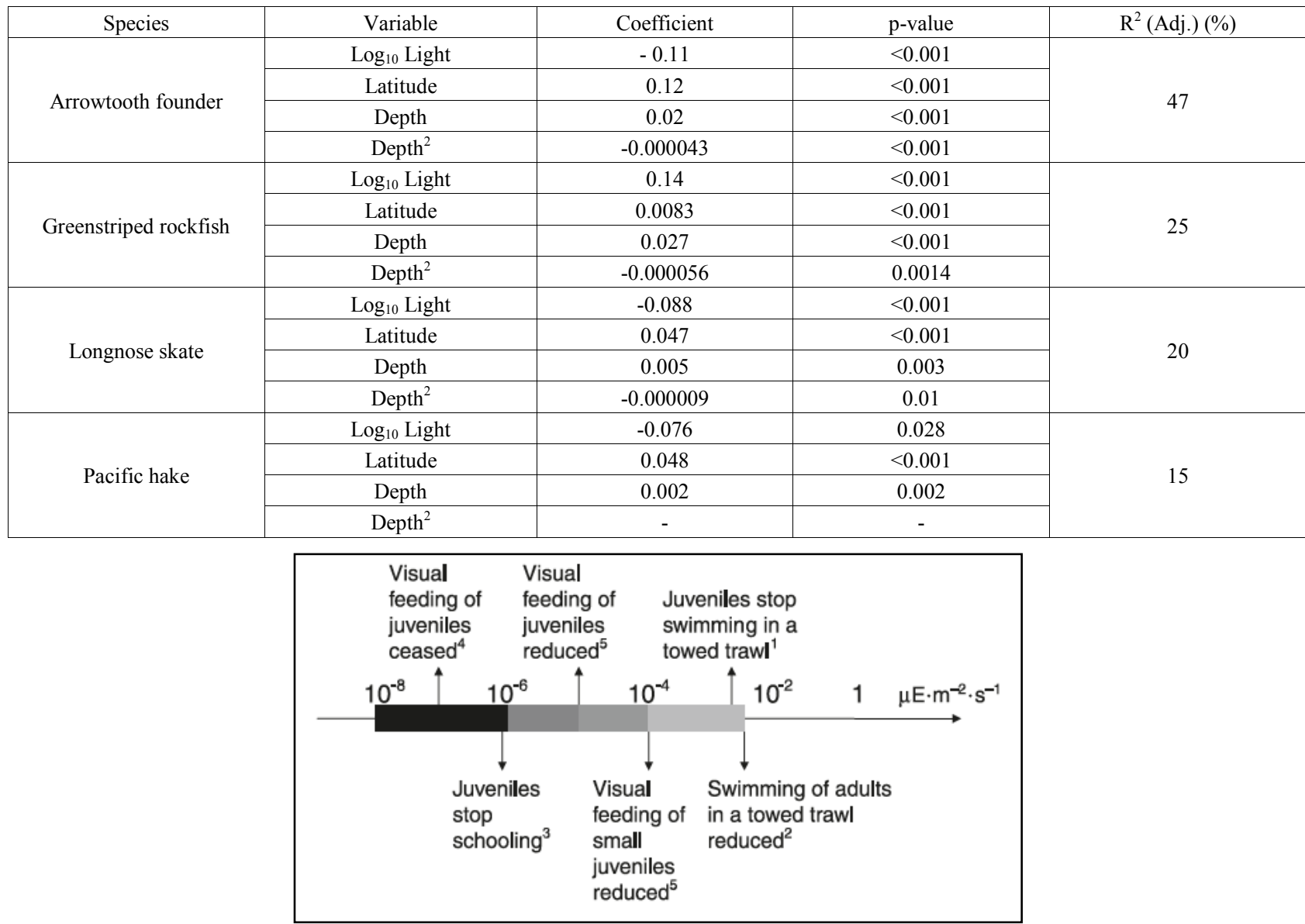

Figure 6. Scheme of light-intensity thresholds known to affect pollock visually mediated behavior. In the Figure, the numbers represent the following works: (1) Olla et al. [18]; (2) Olla et al. [36]; (30 Ryer and Olla [35]; (4) Ryer and Olla [28]; and (5) Ryer et al. [76]. (Source: Kotwicki et al. [72])

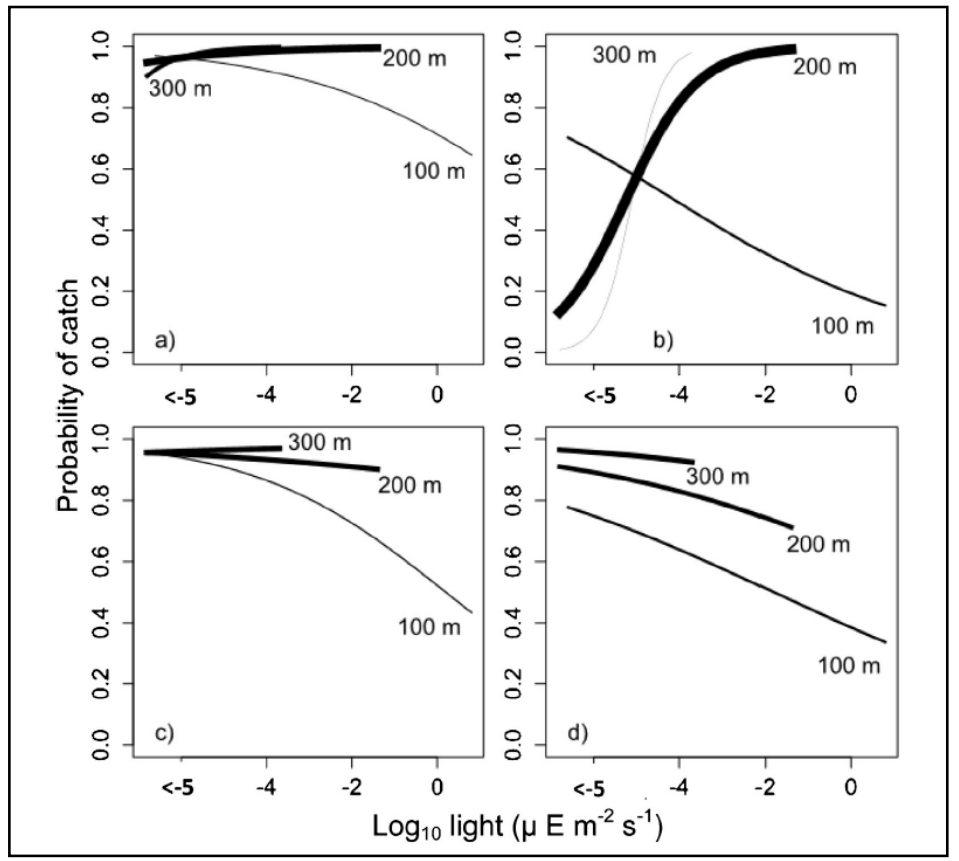

Figure 7. Graphical representation of the probability of catch for: (a) arrowtooth flounder, (b) greenstriped rockfish, (c) longnose skate, and; (d) Pacific hake. For these figures latitude was held constant at $45^{\circ} \mathrm{N}$ and time of day at solar noon. Line thickness is proportional to mean CPUE (kg ha-1) for each depth $\pm 50 \mathrm{~m}$. (Source: Bradburn and Keller [38]). 


\section{Conclusions}

Improving the fishing techniques and enhancing both fishing technology/equipment is critical for fishermen. Appropriate light as fishing source given the scientific evidence that improves both knowledge and understanding about visual capabilities of fish species and how fishery product responses respond to various light intensities during harvest, to achieve sustainable fish catchability based on corresponding attraction/reaction responses warrants further investigation. Increasingly in recent times, there is agreement that fisheries management require guidance about regulation of mesh sizes and use of sustainable/viable escape approach / methodology to help decrease by-catch of undersize / non-target fish species. Improving the fishing gears structure can be viable means of tackling by-catch concerns, which may well increase the understanding about fish behavior and its corresponding sensory capabilities.

To our best knowledge, this is the first review about lighting methods employed in fishery product harvest. Experimental / instrumentation procedures employed in lab-based fishing settings followed by emergent results about fish active escape up to induced stress have been considered. Some general-to-specific implications to resultant quality and postharvest shelf of fishery product(s) can be deduced. Conducted surveys involving how light intensities got mapped at broader scale by locations followed by simulated trawling studies together with the import of vision of fish activity in trawl gear, were described. As fish species depend on vision as sensory means of interaction, further understanding about fish visual capabilities is warranted to evaluate by-catch reduction performance as affected by various light intensities and gear types. Fish - net detectability and guiding-out strategies as it relates to net colour and physical appearance equally deserves further studies. Also, experimental research concerning lighting-fishing endeavors ought to be revamped with light intensities as directed by natural lighting such as the sun and moon, which was depicted in Fig. 1 and this should be encouraged to help supplement existing baseline information. The various lighting positions and its effect on fish catchability under varying intensities may well help to simulate the actual lighting positions of fishing boats, which may offer additional clues to improve both knowledge and understanding about light attraction/reaction response(s) including principles underpinning the specie-specific active escape of fish. Pursuing above-mentioned future studies would help refine the approach of field/real-time fishery product harvest, which in turn would allow for better/improved implementation of responsible fishing activity in compliance within current Common Fishery Policy (CFP) regulations. However, the successes of above future works do not guarantee a convincing end to the long-existent struggle between the fish and fishermen, that is: 'Whilst the fishermen always aim to catch the fish the latter continuously aim to avoid being caught'.

\section{Acknowledgements}

Some financial support from MEDITS is acknowledged. Some financial support from Educare and Skills Training Network is also acknowledged.

\section{REFERENCES}

[1] Gulland J A (1983). FAO/Wiley Series on Food and Agriculture. Food and Agriculture Organization of the United Nations, John Wiley \& Sons: Chichester (ISBN: 0471900273).

[2] Li E, Chen L, Zeng C, Chen X, Yu N, Lai Q, Qin J G (2007). Growth, body composition, respiration and ambient ammonia nitrogen tolerance of the juvenile white shrimp, Litopenaeus vannamei, at different salinities. Aquaculture 265: 385-390.

[3] Okpala COR, Sardo G, Vitale S (2017). On the acclimatization of pelagic fish species juveniles in a close environment: An Atlantic Horse Mackerel case study. Am. J. Animal Vet. Sci. 12(2): 65-70.

[4] Stickney A P (1969). Factors influencing the attraction of Atlantic herring, Clupea harengus harengus, to artificial lights. Fish. Bull. 68(1): 73-85.

[5] Earll R E (1887). In G. Brown Goode (Ed.). The fisheries and fishery industry of the United States. Vol. 1, Sec. V, pp. 417-524.

[6] Andrews CW (1946). Effect of heat on the light behaviour of fish. Proceedings Trans Royal Soc. Canada Services 40(3): 27-31.

[7] Blaxter J H S, Holliday F G T (1963). The behaviour and physiology of herring and other clupeids. In F.S. Russell (Ed.), Advances in marine biology, Vol. 2, Academic Press, London/New York, pp. 261-393.

[8] Liao C H, Chyn S S, Tsai T-Y, Lu H-J. (2007). Fishing capacity and conditions of light fishery under different fishing light intensity. J Fish. Soc. Taiwan 34(2): 207-223.

[9] Arakwa H, Choi S, Arimoto T, Nakamura Y. (1998). Relationship between underwater irradiance and distribution of Japanese common squid under fishing lights of a squid jigging boat. Fish. Sci. 64: 553-557.

[10] Chyn S S, Lee K T, Liao C H (1998). Aggregative behavior of the Swordtip squad (Loligo edulis) under fishing lights in the coastal waters of northern Taiwan. J Fish. Soc. Taiwan 25: $1-15$.

[11] Choi S, Arakwa H (2001). Relationship between the catch of squid, Todarodes pacificus Steenstrup, according to the jigging depth of hooks and underwater illumination in squid jigging boat. J Korean Fishery Soc. 34: 624-631.

[12] Kang W F, Lin Y M, et al. (2001). Study of the technique of light fisheries. Annual Report 2001, Fisheries Research Institute, COA, Taiwan, 2001: 27-48 (In Chinese).

[13] Marchesan M, Spoto M, Verginella L, Ferrero EA. (2005). Behavioural effects of artificial light on species of commercial interest. Fish. Res. 73: 171-185. 
[14] Kang Y H (2003). Light-induced damages in the retina of juvenile emperor red snapper (Lutjanus sebae). Master thesis, Department of Environmental Biology and Fisheries Sciences, National Taiwan Ocean University, Keelung, Taiwan.

[15] Liao C T (2004). A study on fishing composition of torch-lighted fishery in the northern waters of Taiwan. Master thesis, Department of Environmental Biology and Fisheries Sciences, National Taiwan Ocean University, Keelung, Taiwan.

[16] Ryer C H, Barnett L A (2006). Influence of illumination and temperature upon flatfish reactivity and herding behavior: potential implications for trawl capture efficiency. Fish. Res. 81: 242-250.

[17] Sokimi W, Beverly S (2010). Small-scale fishing techniques using light: A manual for fishermen. Secretariat of the Pacific Community, New Caledonia (ISBN: 978-982-00-0449-8).

[18] Olla BL, Davis MW, Schreck CB (1997). Effects of simulated trawling on sablefish and walleye Pollock: the role of light intensity, net velocity and towing duration. J Fish Biol. 50: 1181-1194.

[19] Feist BE, Anderson JJ (1991). Annual Report of Research, Fisheries Research Institute, School of Fisheries, University of Washington, Seattle WA, pp. 100.

[20] Mass AM, Supin A Ya (2007). Adaptive features of aquatic mammals' eye. The Anatomical Record 290: 701-715.

[21] Sardo G (2015). Caratteristiche morfologiche della reina nei cetacei (Morphological characteristics of the cetacean retina). Laurea magistrale (Master) thesis submitted to Faculty of Mathematical, Physical and Natural Sciences (Scuola di Scienze Matematiche Fisiche e Naturali), Università di Bologna, Italy, pp. 56.

[22] Brett JR, Ali MA (1958). Some observations on the structure and photomechanical responses of the Pacific salmon retina. J Fisheries Res Board Canada 15: 815-829.

[23] Woodhead PMJ (1966). The behavior of fish in relation to light in the sea. Oceanography Marine Biol. Ann. Rev. 4: $337-403$.

[24] Ben-Yami M (1976). Fishing with light. FAO of the United Nations. Fishing News Books Ltd., London, pp. 121.

[25] Kawamura G (1986). Vision and behavior of fish in the vicinity of fish lamp. Proceedings of International Conference for Development and Management of Tropical Living Aquatic Resources, Serdang, Malaysia, 2-5 Aug. 1983, pp. 197-204.

[26] Freón P, Misund OA (1999). Dynamics of pelagic fish distribution and behavior: effects on fisheries and stock assessment. Blackwell Science, Oxford, pp. 348.

[27] Ciriaco S, Marchesan M, Verginella L, Vinzi E, Ferrero EA, Spoto M (2003). Preliminary observations on the effects of artificial light on the marine environment, with special reference to three fish species of commercial value protected by Miramare Marine Reserve. Bolletino di Geofisica Teorica ed Applicata 44 (1): 19-26.

[28] Ryer CH, Olla BL (1999). Light-induced changes in the prey consumption and behavior of two juvenile planktivorous fish. Marine Ecol. Progress Series 181: 41-51.

[29] Ryer CH, Olla BL (2000). Avoidance of an approaching net by juvenile walleye Pollock Theragra chalcogramma in the laboratory: the influence of light intensity. Fish. Res. 45: 195-199.

[30] Higgs D M, Fuiman L A (1996). Light intensity and schooling behaviour in larval gulf menhaden. J Fish Biol. 48: 979-991.

[31] Dragesund O (1958). Reactions of fish to artificial light, with special reference to large herring and spring herring in Norway. ICES J Marine Sci. 23: 213-227.

[32] Lythgoe J N (1979). The ecology of vision. Clarendon Press, Oxford.

[33] Valen R, Edvardsen R B, Søviknes A M, Drivenes Ø, Helvik JV (2014). Molecular evidence that only two opsin subfamilies, the Blue Light - (SWS2) and Green Light-Sensitive (RH2), Drive Color Vision in Atlantic Cod (Gadus morhua). PLoS One 9(12): e115436.

[34] Marchesan M, Spoto M, Ferrero EA (2009). Impact of artificial light on behavioural patterns of coastal fishes of conservation interest. Varstvo Narave 22: 117-136.

[35] Ryer CH, Olla BL (1998). Effect of light on juvenile walleye Pollock shoaling and their interaction with predators. Marine Ecol. Progress Series 167: 215-226.

[36] Olla BL, Davis MW, Rose C (2000). Differences in orientation and swimming of walleye Pollock Theragra chalcogramma in a trawl net under light and dark conditions: concordance between field and laboratory studies. Fish. Res. 44: 261-266.

[37] Land MF, Nilsson DE (2002). Animal Eyes. Oxford University Press. Oxford.

[38] Bradburn MJ, Keller AA (2015). Impact of light on catch rate of four demersal fish species during the 2009-2010 US west coast groundfish bottom trawl survey. Fish. Res. 164:193-200.

[39] Gabr M, Fujimori Y, Shimizu S, Muira T (2007). Trawling experiment in a circular water to assess the effects of towing speed, light intensity, and mesh shape on active escape of undersized fish. Fish. Sci. 73: 557-564.

[40] Helfman GS (1993). Fish behavior by day, night and twilight. In Pitcher, T.J. (Ed.): Behaviour of Teleost fishes $2^{\text {nd }}$ Edition. Chapman \& Hall, London, pp. 479-512.

[41] Pankurst P M, Hilder P E (1998). Effect of light intensity on feeding of striped trumpeter Latris lineata larvae. Marine Freshwater Res. 49: 363-368.

[42] Blaxter J H S (1964). Spectral sensitivity of the herring, Clupea harengus L. J Experimental Biol. 41: 155-162.

[43] Varanelli C C, McCleave J D (1974). Locomotor activity of Atlantic salmon parr (Salmo salar L.) in various light conditions and in weak magnetic fields. Animal Behaviour 22: 178-186.

[44] Yang Y R (1986). Response of Marbled Sole to the white lights. Bull. Korean Fish. Soc. 19(6): 558-562.

[45] Marchesan M, Spoto M, Verginella L, Ferrero EA (2003). Behavioural effects of artificial light on three fish species of commercial interest. Paper presented in ICES/FAO Symposium 'Fish behaviour in exploited ecosystems, 23-26 June 2003, Bergen, Norway.

[46] Owino P, Mwamburi M, Kioko S (2011). Design and Construction of a Fishing Light Attractor. Ist Young Scientists 
MSSEESA Conference on Materials Science and Solar Cell Technology, Abstract Number 27.

[47] Pavolv DS, Tjurjokou SN (1995). Reactions of dace to linear accelerations. J Fish. Biol. 46: 768-774.

[48] Chyn SS, Liao CH, Kang WF, Tsai TY (2006). Study on the capacity of fishing lamps and catch per unit effort of stick-held net in waters off northern Taiwan. J Fish. Soc. Taiwan 14: 49-65.

[49] Aglen A, Engås A, Huse I, Michalsen K, Stensholt BK (1999). How vertical fish distribution may affect survey results. ICES J. Marine Sci. 56: 345-360.

[50] Kirk JTO (1996). Light and photosynthesis in aquatic ecosystem. $2^{\text {nd }}$ Edition. Division of Plant Industry, Commonwealth Scientific and Industrial Research Organization, Cambridge University, Canberra, Australia, pp. 12 .

[51] Beltestad AK, Misund OA (1988). In Proceedings of World Symposium on fishing gear and fishing vessel design. The Marine Institute St. John's, Newfoundland. pp. 190-192.

[52] Hawryshyn CG (2003). In Collin, S.P. \& Marshall, N.J. (Ed.): Sensory processing in aquatic environment. Springer Verlag, New York, pp. 252-265.

[53] Blaxter JHS, Parrish BB, Dickson W (1964). In Fishing Gear of the World, FAO Document, Vol. 2, p. 529-536.

[54] Yang, Y-R. (1986). Response of rock trout to the white lights. Bull. Korean Fish. Soc. 22(4), 55-60.

[55] Olla BL, Davis MW (1990). Behavioral responses of juvenile walleye pollocj Theragra chalcogramma Pallas to light, thermoclines and food: possible role in vertical distribution. J Exp Marine Biol Ecol. 135: 59-68.

[56] Meager JJ, Moberg O, Strand E, Utne-Palm AC (2010). Effects of light intensity on visual prey detection by juvenile Atlantic cod (Gradus morhua L.). Marine Freshwater Behav. Physiol. 43(2): 99-108.

[57] Bryhn A C, Königson S J, Lunneryd S-G, Bergenius MAJ (2014). Green lamps as visual stimuli affect the catch efficiency of floating cod (Gadus morhua) pots in the Baltic Sea. Fish. Res. 157: 187-192

[58] Hannah R W, Lomeli M J M, Jones SA (2015). Tests of artificial light for bycatch reduction in an ocean shrimp (Pandalus jordani) trawl: strong but opposite effects at the footrope and near the bycatch reduction. Fish. Res. 170: 60-67.

[59] Glass C W, Wardle C S (1995). Studies on the use of visual stimuli to control fish escape from codends. II. The effect of a black tunnel on the reaction behaviour of fish in otter trawl codends. Fish. Res. 23: 165-174.

[60] Glass C W, Wardle C S, Gosden S J, Racey D N (1995). Studies on the use of visual stimuli to control fish escape from codends. I. Laboratory studies on the effect of a black tunnel on mesh penetration. Fish. Res. 23: 157-164.

[61] Walsh SJ, Hitckey WM (1993). Behavioural reactions of demersal fish to bottom trawl at various light conditions. ICES
J. Marine Sci. Symp. 196: 68-76.

[62] Hannah R W, Jones S A (2012). Evaluating the behavioral impairment of escaping fish can help measure the effectiveness of bycatch reduction devices. Fish. Res. 131: $39-44$.

[63] Fernö A (1993). Advances in understanding of basic behaviour: consequences of fish capture studies. ICES J Marine Sci. Symp. 196: 5-11.

[64] Chopin F S, Arimoto T (1995). The condition of fish escaping from fishing gears - a review. Fish. Res. 21: 315-327.

[65] Schreck C B (1990). Physiological, behavioral, and performance indicators of stress. Am Fish. Soc. Symp. 8: 29-37.

[66] Olla B L, Davis M W, Schreck C B (1992). Comparison of predator avoidance capabilities with corticosteroid levels induced by stress in juvenile coho salmon. Trans Am Fish. Soc. 121: 544-547.

[67] Olla B L, Davis M W, Schreck C B (1995). Stress-induced impairment of predator evasion and non-predator mortality in Pacific salmon. Aquaculture Res. 26: 393-398.

[68] Barton B A, Iwama G K (1991). Physiological changes in fish from stress in aquaculture with emphasis on the response and effects of corticosteroids. Ann. Rev. Fish. Diseases 1: 3-26.

[69] Hall M A (1998). The ecological view of tuna-dolphin problem: impacts and trade-offs. Rev. Fish Biol. Fish. 8, 1-34.

[70] Witherington B E (1997). The problem of photopollution for sea turtles and other nocturnal animals. In: Clemmons, J. R. and Bucholz, R. (Ed.): Behavioural approaches to conservation in the wild. Cambridge University Press, Cambridge.

[71] Lawson GL, Rose GA (1999). The importance of detectability to acoustic surveys of semi-demersal fish. ICES J Marine Sci. 56(3): 370-380.

[72] Kotwicki S, De Robertis A, von Szalay P, Towler R (2009). The effect of light intensity on the availability of walleye Pollock (Theragra chalcogramma) to bottom trawl and acoustic surveys. Can J Fish. Aquat. Sci. 66: 983-964.

[73] Wakabayashi K, Bakkala RG, Alton MS (1985). Methods of the US-Japan demersal trawl surveys. INPFC Bulletin 44: $7-29$.

[74] Hjellvik V, Godø O R, Tjøstheim D (2004). Decomposing and explaining the variability of bottom trawl survey data from the Barents Sea. Sarsia 89: 196-210.

[75] Fujimori Y, Shiode D, Baba N, Shimizu S (1999). Behavior of juvenile walleye Pollock Theragra chalcogramma in relation to time and illuminance. Nippon Suisan Gakkai Shi 65: 26-32.

[76] Ryer C H, Lawton A, Lopez R J, Olla B L (2002). A comparison of the functional ecology of visual vs. non-visual foraging in two planktivorous marine fishes. Can. J Fish. Aquatic Sci. 59 (8): 1305-1314. 